\title{
Problem-solving and coordination-governance: advances in a competence-based perspective on the theory of the firm*
}

\author{
Benjamin Coriat \\ Professor of Economics - Université Paris 13 \\ Giovanni Dos \\ Director, D octorate in Economics, Sant'Anna School of Advanced Studies, Pisa, Itália
}

\section{ABSTRACT}

Thepaper drawsupon theconclusions of a project ( $D$ ynacom) sponsored by theEuropean U nion, on the nature and dynamics of organizational competences and capabilities. Such an analysis attemptsto identify the relationships between thelatter and various forms of knowledge embodied in organizations.

Secondly, it compares a capability-centered view of the firm with other approaches including traditional agency theory and transaction costs economics. Finally, some policy implications are presented.

KEYWoRDS I organizational capabilities; competences; resource-based theories; routines; technological knowledge; problem-solving.

JEL-Codes I 011 - M acroeconomic Analysis of Economic D evelopment; 041 Multisectoral G rowth M odels.

\footnotetext{
* This work is partly based on the Final Report of the Dynacom Project, supported by the European Union (DG XIII, TSER): cf. Dosi G., B. Coriat K. Pavitt (2000). For correspondence, G. Dosi, Laboratory of Economics and Management (LEM), Sant'Anna School of Advanced Studies, Piazza dei Martiri della Libertá, Pisa, Italy, Tel. +39-050-883343, Fax +39-050-883344, E-mail: lem@sssup.it, web page: http://www.sssup.it/ LEM/
} 


\section{Resumo}

0 artigo baseiz-senas conclusõesdeum projeto ( $D$ ynacom), apoiado pelaU nião Européa, sobrea natureza e a dinâmica das competências e capacitações organizacionais. Tal análise busca identificar as relações entreestas competênciase capacitações eas várias formas de conhecimento incorporado nas organizações.

Em segundo lugar, o artigo compara a visão da firma centrada sobre as capacitações (visão baseada em recursos) com outras abordagens - queincluem a abordagem tradicional dateoria do agente principal ea economia dos custos de transação. Finalmente, são apresentadas algumas implicações depolítica.

PalaVRAS-CHAVE | capacitações organizacionais; competências; visão baseada em recursos; rotinas; conhecimento tecnológico; solução de problemas.

CódigosJEL | 011 - Análise macroeconômica do desenvolvimento econômico; 041 M odelos de crescimento multissetorial.

\section{Introduction}

O n purpose, we have organized this paper, so to speak, "bottom-up", building upon what we believe are complementary elements of "valueadded" along diverse threads of empirical analysis. A highly complementary endeavour, however, has been to induce persistent feedbacks with theoretical advances. H ere, "theory" is given a broad span - as it should be - ranging from "appreciative theorizing" (i.e. history-based, largely qualitative generalizations) all the way to formal modeling inevitably implying some sort of bold "reduced form" abstractions.

\section{Evolutionary economics and firm capabilities}

A fundamental proposition in evolutionary economics is that firms have ways of doing things that show strong elements of continuity. A related and equally fundamental proposition is that firms have distinctive ways of doing things: firms are generally heterogeneous even in the ways they 
accomplish functionally similar tasks, to say nothing of the large-scale differences that separate the chemical firm, the automobile manufacturer, the mass retailer, and the hospital. Taken together, these propositions set the stage for the dynamic interplay of the evolutionary triumvirate of variation, selection, and retention. Variety in the form of heterogeneous firm behaviour patterns gives the market selection process something to work on; because the pattern persist, the market's selection and promotion of successful ones has significant systemic consequences over time.

Research on capabilities advances the evolutionary economics agenda in four significant ways. First, it provides concrete examples and specific empirical evidence that illustrates and supports the view of firm behaviour taken in evolutionary theory. The analysis of firm capabilities illustrates one very fruitful way of conceptualizing the elements of continuity and idiosyncrasy that are central to the evolutionary view of firm behaviour. To the best of our knowledge, no student of firm capabilities has ever proposed that firm capabilities often change radically in short periods of time, except perhaps by the outright acquisition of another firm that al ready possesses different capabilities. Rather, the emphasis is on the accumulation of capabilities and the fact that the options for further development at each point of time are sharply constrained by the heritage of the past. ${ }^{1}$

The second contribution involvestherelationship between capabilitiesand organizational routines. Routines play a central role in the formulation of evolutionary theory offered by Nelson and Winter. In their introductory discussion, they noted that much business behaviour is not routine within the ordinary meaning of that term, but then remarked '(T hepoint) ... isthat most of what is regular and predictableabout business behaviour is plausibly subsumed under theheading "routine", especially if we understand that term to includethe relatively constant dispositions and strategic heuristics that shapetheapproach of a firm to the non-routine problems it faces' (1982:15).

The story of the development of capabilities in a firm is very much a story of the shaping role of 'relatively constant dispositions and strategic heuristics' that providean element of continuity that extends even over time 
spans long enough for radical change to accumulate in the firm's specific performances. Thus, the capabilities discussion relates specifically to a realm of behaviour infused with intentionality, conscious deliberation, planning, and expertise - as contrasted with the quasi-automatic character of performance of low-level operating routines. And it shows how these elements of intelligence and intentionally rational calculation not only coexist with, but give expression to, the historically grounded uniqueness of theindividual firm.

The third contribution is closely akin to the second. Precisely because the devel opment of capabilities also includes elements of intentionality and deliberation, the capabilities discussion provides a bridge between the predominantly descriptive concerns of evolutionary theory and the prescriptive analysis of firm strategy. Accurate description requires acknowledgement of the role of intentionality; likewise, sound advice must be founded on an accurate characterization of the system the decision makers are guiding. Thus the two areas of inquiry are mutually supportive, notwithstanding the substantial difference between their focal concerns.

Evolutionary economics has long been identified with an emphasis on the role of institutions in economic life, and this long-standing connection has recently been revitalized (H odgson, 1988 and 1993). T he narrower but still extensive set of institutions that shape a nation's science and technology resource and, generally, innovative abilities is another area of institutional and policy concern that has a long-standing connection to evolutionary economics. ${ }^{2}$ It is hard to review the history of the aircraft industry, or of computers, or biotech, or many other industries, without getting the distinct impression that something more is going on than the exploitation of the 'given' production functions of firms. Evolutionary economists view firms as building their capabilities in an institutional and policy context, and the exploration of the connections to those contexts remains very much on the research agenda (M etcalfe, 1994).

Last but not least, fourth, evolutionary theories of economic changefinally begin to meet institutionally embedded analyses of incentive governance.

Within any organization, capabilities, in principle aimed to 'solve

2 On the germane field of 'national systems of innovation' see Lundvall (1992) and Nelson (1993). 
problems' in thebroadest sense - ranging from carrying a passenger across the Atlantic to more purposeful activities of search for new drugs or new machines - come anyhow together with specific mechanism governance of potentially conflicting interests and incentives. Indeed, the links (and, over time, the coevolution) between organizational capabilities and governance structures is another major field of inquiry ahead [for some hypotheses and empirical interpretations cf. Coriat and D osi (1998a); Weinstein and Azoulay (1999)(B) and Coriat $(2000)(A)]$.

\section{Firms capabilities and strategic management}

As many observers have noted, the past decade or so has seen a marked swing in the attention focus of scholars and practitioners interested in business strategy. A mong the aspect of strategic doctrine that now capture attention, issues surrounding the quality of firm capabilities now loom very large. A number of factors have contributed to this development. $0 \mathrm{n}$ the academic side, there is an element of the familiar phenomenon of the swinging pendulum of attention: the concerns with capabilities followed a period in which strategy research had been re-energized by economic concepts drawn from industrial organization economics and focused primarily on the firm's relation to its competitive environment. As often happens, one of the truths discovered in this research programme was that its orienting ideas were not as fruitful in illuminating the key issues as had been hoped. The quest for the sources of competitive advantage turned back toward the internal workings of the firm, and in particular to the development of Edith Penrose's idea (1959) that the profitability and growth of a firm should be understood in terms of its possession and development of uniqueand idiosyncratic resources.

Scholars who identify themselves with the "resource-based view" examine the question of what sorts of resources confer lasting competitive advantages, how these advantages can be extended "leveraged", and what considerations prevent the elimination of the gap between the cost of the resources and the market value of the output produced. M any discussions in this vein seem to imply that firm resources are "idiosyncratic" in only a weak sense; they are relatively discrete and separable from the context of the firm 
and are the sorts of things that would naturally carry a market price. $0 \mathrm{n}$ this interpretation, the resource rubric does not subsume capabilities. Some authors, notably D ierickx and Cool (1989), offer a sharply contrasting view, suggesting that competitively significant resources are gradually accumulated and shaped within the firm, and are generally non-tradable. Unique, difficult-to-imitate capabilities acquired in a protracted process of organizational learning are example of the sorts of resources they see as sources of competitive advantage.

Another recent theme in the strategy literature is the idea that the most distinctive role of the business firm in the economic system is the way it brings knowledge to bear on productive effort. This and related ideas have been discussed under the heading of the "knowledge-based theory of the firm" [G rant (1996), Kogut and Z ander (1992), and D osi and M arengo (1994)].3 As with the notion of resources, this discussion converges with the capabilities discussion in proportion as the knowledge is conceived as know-how embedded in the organization's activities, as opposed to passive, library-like stocks in the heads of participants.

There is, however, much more to the rising concern with capabilities than simply the swinging pendulum of scholarly interest. O ne important background fact (in the U SA) is the stock market's skepticism toward unrelated diversification, which has been manifested quite consistently for at least fifteen years (even if one always argues that this phenomenon itself is a scholarinduced fad!). Episodes like Sears R oebuck's 1992 retreat from its strategy of diversification into financial services, and the broadly similar evolution at American Express in 1993 and after, illustrated the power of the market to "jerk the chain" of wandering CEO s and force a retreat to the "core business". ${ }^{4}$ That being the case, it is unsurprising that managers and consultants became inclined to focus more on the relatively concrete and specific issues affecting the individual firm's competitiveness in particular markets. Another impulse in the same direction was provided by the rising concern with American manufacturing vis-à-vis] apanese competition in the early and mid-1980s.

3 For an earlier discussion with similar emphasis but cast in terms of reforming the theory of production, see Winter (1982)

${ }_{4}^{4}$ For a more detailed discussion of the relationship between capabilities and diversification patterns, see Teece et al. (1994). 
So far has thistrend progressed that $\mathrm{M}$ ichael Porter of $\mathrm{H}$ arvard, a longtime leader in the strategy field who is active in both the academic and consulting segments, has recently felt compelled to enter an objection in the form of an article title "W hat Is Strategy?" beginning with Section I: "O perational Effectiveness I s N ot Strategy" (Porter, 1996). It remains to be seen whether this assessment will do much to diminish the prevailing interest in capabilities-based competition.

Although the discussion of capabilities issues has been quite extensive in both the business press and the academic strategy literature, the fund of solid empirical research that is specifically on the strategic aspects of the subject has accumulated rather slowly. ${ }^{5}$ Asa result, much of the discussion has remained at a relatively high level of abstraction. Webelievethat we havecontributed important insightshel ping to operationalize $C P$ in thestrategic domain.

In particular Teece, Pisano and Schuen (2000)(A) present an ambitious attempt to conceptualize different forms of competence and relate them to both organization theory and strategic management. A general premise is that distinctive governance modes do not replicate either pure market arrangements or any "nexus of contracts".

Given that, we identify the specificities of each firm in terms of (a) organizational processes (including their operating routines), (b) positions (broadly defined to cover their specific assets, their location along the value suppliers and customers), and (c) paths (i.e. their patterns of change in the former two sets of characteristics). A theme which is emphasized - common also to most of the other contributions - is the stickiness over time of distinct organizational capabilities and, thus, also the constraints which the past learning history of the organization puts upon the degrees of discretionality of strategic management.

This perspective on organizations and organizational learning clearly shifts the focus of analysis from either product positioning or "clever strategizing" to the processes of problem-solving and organizational governance, and, dynamically, to competence-enhancing strategies.

For broader discussion of the recent emphasis on capabilities in the strategic management literature, see Rumelt ef al. (1991), Teece et al. (1997), and Stalk et al. (1992). The discussion in Robert Grant's excellent textbook

illustrates the appearence of these ideas in the business school curriculum (Grant, 1995, ch. 5] 
W ithin such a general perspective let usjust signal herewhat we consider a particularly novel angle of observation promisingly linking analytical and normative dimensions, - namely Warglien (1999)(B) - on intra-organizational dynamics. We have al ready mentioned some of its interpretative implications. From a normative point of view, it points at the crucial importance of somesort of meta-competences attempting to "carefully tune the exploitation/ exploration trade-off", whereby "the portfolio of projects should comprise at any time a balanced set of new traitswhich present high risk but higher development potential, and well established traits that provideresourcesfor supporting the cost and the risk of exploitation..." (Warglien, ibid.). N ote that this perspective on intraorganizational knowledge dynamics involvesa major "re-thinking of traditional management tools such as team staffing and nobility, incentive policies and information storageand retrieval - conceptualizing them as tools for setting the parameter of intra-firm dynamics" (ibid).

$M$ ore specifically, in such a context, the management of a variety of exploration trajectories implies a view of an organization as an "artificial ecology" - borrowing from Levinthal (2000)(A) - wherein managers look somewhat like contemporary bioengineers, trying to "fine tune" ex-ante the discovery of new traits and ex-post test and select amongst them (Indeed the analogy ischilling, were one to extrapolate the rates of managerial success to the biological domain!).

\section{CP on organization theory, in the broader context of contemporary theories of the firm}

It isworth comparing the $\mathrm{CP}$ on thetheory of the firm with the "orthodox view - which for brevity we equate to the "orthodox" agency theory (OA henceforth) and transaction cost economics (TCE henceforth). ${ }^{6}$

Given the growing number of detailed accounts of $C P$ and germane views of organizations, such as "resource-based" theories, one can effort to be particularly telegraphic [N elson and Winter (1982) and also in Dosi and M arengo (1994), Kogut and Zander (1992 and 1995), N elson (1991), Teece

6 This part of the paper is largely based on Dosi and Marengo (1999) (B), Coriat (2000b) (B). 
and Pisano (1994), Teeceet al. (1994), M adhok (1996), Conner and Prahalad (1996), Leonard-Barton (1995), W inter (1988)].

The phenomena the theory addresses prominently feature heterogeneity among firms and the sources of persistent competitive advantage. For this primary purpose, it elaborates a theory of the nature of the firm whose perspective departs quite significantly from standard Agency views but also from the Coasian one. First of all, firms are not seen exclusively as loci of coordination, but also, and equally important, as loci of creation, implementation, storage and diffusion of productive knowledge (cf. Winter, 1982). Second, and relatedly, the very existence of firms is not considered in terms of a departure from the original state of nature in which coordination is carried out entirely by competitive markets, but in terms of their being the primary loci of the process of division of labour, i.e. of the creation of those separable units which competitive markets might (or might not) coordinate efficiently. Equival ence between markets and organizations might well hold (lacking transaction and bureaucratic costs) for a given state of division of knowledgeand labour, but it doesnot hold if thelatter arethemsel ves dependent upon the organizational structure [moreon this "anti-C oasian" perspectivein $M$ arengo (1999) and M arengo et al. (2000)(B)].

In addition to thisinquiry in thesourcesand consequences of heterogeneity, $\mathrm{CP}$ attempts to interpret both the vertical and horizontal boundaries of the firm (cf. Teeceet al., 1994); it investigatestheproperties of different forms of internal organization; it tries to establish the sources of differential performance among firms; it analyses the processes by which particular organizations became what they are(i.e. theunderlying evolutionary processes).

As a first approximation, and notwithstanding the limitations discussed in Coriat and Dosi (1998 a), it tries to accomplish the above tasks by focussing on organizations as repositories of problem-solving knowledge as distinguished from sheer information and by studying some salient properties of knowledge accumulation and the ways the latter coevolve with organizational structures and practices (including, of course, routines but also managerial heuristics and strategies).

0 rganizational specificities and persistently different revealed performances, are interpreted also on the grounds of path-dependence in 
knowledge accumulation and inertial persistence of organizational traits. Bounded rationality, in its broadest meaning, is the norm. Its general sources includethe "complexity" and procedural uncertainty associated with problemsolving procedures [cf. D osi and Egidi (1991), M arengo et al. (2000)(B)] and the intrinsic "opaqueness" of the relationship between actions and environmental feed-backs, so that it is seldom obvious, even ex-post, to state how well one did and why (cf. M arch, 1994).

Theanalysisis, or ought to be, undertaken both in terms of comparative properties of different organizational forms (a methodology deeply shared with TCE) and modal learning processes (al most entirely absent from TCE), properly accounting for initial conditions and for their embeddedness into broader institutional set-ups, such as those governing the markets for labour, financeand products.

In CP, as discussed with several original insight in Levinthal (2000)(A), organizational competences and capabilities are partly a collective property of ensemble of organizational routines and learning heuristics (and al so, 'cultures', 'visions', and strategic orientations) and provides an appealing theoretical framework for their analysis.

Key features in this respect are the notion of (a) complementarity and (b) interdependenceamong organizational routines and complementary assets. A crucial consequence concerns what one could call the 'competitiveness diagnostic' of corporate performances: precisely because of the (non-linear) interrelatedness in the contribution of the various organizational traits to overall performances, 'credit assignments' is a difficult exercise.

Relatedly, in terms of organizational learning, 'local' exploration and adjustments are likely to be rule, since otherwise one is likely to lose any grasp on the relationships between causes (i.e. changes in organizational behaviour) and effects (i.e. changes in relieved performances). But a fundamental corollary of all thisis also that organizations are likely to end up (quasi) stuck into local peaks of the 'fitness landscape', using Levinthal (2000)(A) and M arengo et al. (2000)(B) terminology (i.e. roughly speaking the mapping between organizational traits and 'competitiveness'), with low probabilities of exploring radically diverse organizational arrangements.

It is useful to provide a sort of "bird-eye" comparative assessment 
among $C P, T C E$ and the orthodox view of agency $(O A)$ where by the latter we mean the whole class of interpretations grounded on equilibrium contracting with fully rational far-sighted agentsunder asymmetric/incomplete information.

In table 1 wehighlight some major distinguishing features.

Table 1. Orthodox agency, transactions costs economics and competence perspectives: a comparative appraisal.

\begin{tabular}{|c|c|c|c|}
\hline $\begin{array}{l}\text { Dimensions of analysis and } \\
\text { Theonetical huilding hlocks: }\end{array}$ & Orthodex Agency & Tratasctios Ceat Feonumies & $\begin{array}{l}\text { Comperence Gand Fodurionary) } \\
\text { Perspectives }\end{array}$ \\
\hline $\begin{array}{l}\text { Probiem-solving/cognicbon? } \\
\text { knawialgs }\end{array}$ & No & $\begin{array}{l}\text { Nor so far fhut ses Wifiamsin. } \\
199 \% \text { and 199\%? }\end{array}$ & Yas fernusal dinumaion of analyial \\
\hline Incentive govertuance & 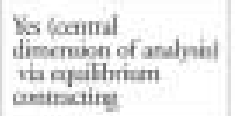 & $\begin{array}{l}\text { Yes, pascly va onganization } \\
\text { as whecinuses for equilituium } \\
\text { contracting }\end{array}$ & 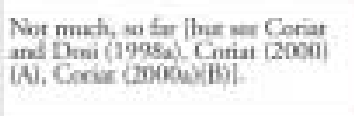 \\
\hline $\begin{array}{l}\text { Behwisea } \\
\text { mikro-foundarions }\end{array}$ & $\begin{array}{l}\text { Rerkoct, farsightmal } \\
\text { matimaliry }\end{array}$ & $\begin{array}{l}\text { Baundal miasdicy wih } \\
\text { "Garightudnes" }\end{array}$ & 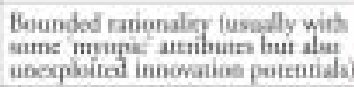 \\
\hline Organizatimnal behasies & 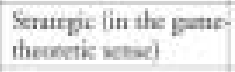 & Cotrocoenmining & Driven by mutines heuristics cte. \\
\hline Learning & No & Nea wat & Yo lertutzal dinmaion of analyial \\
\hline Dnitci ef analysis & 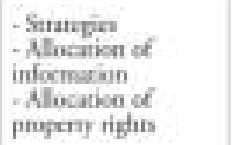 & Nint $\infty$ far & Yes factinal diticnabon of andris) \\
\hline $\begin{array}{l}\text { Nob-conoetic dimensions } \\
\text { of arganizations }\end{array}$ & $\begin{array}{l}\text { Not as oniginal } \\
\text { timentoni }\end{array}$ & No & Trwes. mus. Afentigy-buildieg, enc \\
\hline
\end{tabular}

In order to emphasise the differences, consider first a major divide concerning the primary dimensions of analysis, which in the case of both $\mathrm{OA}$ and TCE regard essentially incentive governance, while CP focuses on the problem-solving dimensions of organizations. In a nutshell CP's "primitive story", which finds ancestors in the work of $\mathrm{H}$ erbert Simon as well as multiple streams of organization theory, carries a good deal of "cognitive" emphasis, while it tends to censor (as a first approximation, which is ripe time to overcome!) all governance issues which arise from potentially conflicting interests, opportunism, etc. W illiamson (1999a and 1999b) is certainly right 
in reminding us that, taken at face-value, that primitivestory implies a utopian view of actors as benevolent cooperators.

On the other hand, the same epistemological status can be also attributed to the primitive story which is implied by both $O A$ and TCE, whereby one censors the fact that organizations essentially carry complicated procedures to do complicated things such as producing airplanes, shoes, transportation services for peopleand goods, etc. and that they do it moreor less well for reasons which are partly independent from sheer incentive alignment issues. Thus, in the OA and TCE "utopia", the implicit ceteris paribusassumption is that organizations naturally possess, in their "optimal" form, theknowledge required to carry out such complex tasks and, moreover, that this optimal knowledge in itself is independent from the actual organizational structure. Themembers of the "utopian" organization depicted by $O A$ and TCE are not actually engaged in acquiring and implementing the knowledge necessary to do the complex things actual organizations do, but are only engaged in playing among themselves devious games of cheating, hiding, double crossing, etc.

$\mathrm{N}$ eedless to say, the crucial issue beyond the caricature is what kind of empirically robust propositions each view is ableto generate. In this respect, one of the basic tenets of $\mathrm{CP}$ is that the whole domain of accumulation and social distribution of knowledgecannot bereduced to a sheer matter of either incentives or property rights allocation. Witness on that, the ample literature on the economics of innovation and organizational learning al ready mentioned in the foregoing sections trying to establish a few "stylised facts" on the patterns of learning at the level of firms, industries and countries, which may be hardly interpreted as equilibrium responses incentives or to property rights distributions.

$H$ aving said that $C P$ is beginning to tackle the "grand" research programme, sketched Coriat and D osi (1998a), building on classic insight such as those from M arch and Simon (1993), whereby evolutionary, competence-based theory of the firm begin to take on board incentive al ignment issues and moregenerally thepolitical dimensions of organizational arrangements: amongst other contributions, see in particular Coriat (2000a)(B) on the arrangements governing both knowledge distribution and political leverages in C omplex Product Systems. 
In parallel, advances are being made in the development of a formal theory of organization as problem-solvers, see in particular $\mathrm{M}$ arengo et al. (2000) (B), wherewestudy analytically the ways different patterns of division of labour shapeand constrain search processes in high dimensional problem spaces. Examples of such search processesareall thoseproblemsrequiring the coordination of a large number of interdependent "elements" whose functional relationships are, to a good degree, opaque to the organizational members themselves.

$H$ ere by "elements" wemean elementary physical acts- such as moving one piece of iron from one place to another - and elementary cognitive acts - such as applying inference rules. Relatedly, problem-solving can be straightforwardly understood as combination of elementary acts leading to a feasible outcome (e.g. the design and production of an engine, the discovery and testing of a chemical compound, etc.).

In this perspective, one presents a quite general formal framework enabling the exploration of the problem solving properties of diverse patterns of division of labour and routine-clustering practices, ranging over a continuum that notionally spans from totally decentralised market-like mechanism to fully decentralised coordination processes.

M oreover, diverse organizational forms map into diverse

I. problem representations;

II. problem decompositions;

III. task assignments;

IV. heuristics for and boundaries to exploration and learning;

V. mechanismsfor conflictsresolution over interests, and, equally important, over alternati ve cognitiveframesand problem interpretations.

$W$ ith respect to these dimensions, to repeat a telegraphic caricature we are rather fond of, one might think, at one extreme, of an archetypeinvolving complete, hierarchical, ex ante representations, precise task assignments according to well defined functions/tasks, quite tight boundaries to exploration - "learning" being itself a specialized function - and, if all that works, no need for ex-post conflict resolution.

The opposite extreme archetype might be somewhat akin university 
departments, with a number of representations at least as high as the number of department members, fuzzy decompositions, little task assignments and loose boundaries to exploration, fuzzy conflict resolution rules, etc.

Clearly, Taylorist/ Fordist organizational forms tend to be nearer the former archetype, while e.g. the design and production of complex product Systems are more alike the latter. $\mathrm{H}$ owever, at a closer inspection, one begins to identify a set rich of discrete types of organizational arrangements, and with that al so diverse learning patterns.

\section{Competences and organizational performances: some "diagnostic" conclusions and policy implications}

Theanalyses of competenceprofiles and patterns of organizational learning have often come together with a few, admittedly preliminary, explorations of the impact of competences themselves upon technological and economic performances and of broader policy implications.

In the following we shall discuss some of them. In particular, in order to highlight a few policy issues stemming from our study it is useful to place the findings in the context of the broader picture concerning comparative patterns in science, technology and competitiveness. This is what we shall succinctly do in the following [(drawing also on the results of the other projects: cf., in particular, Fagemberg, G uerrieri and Verspagen (1999) and Edquist (1997)].

A caveat is required: some of the policy issues rai sed by related studies are both quite crucial for European policies and also quite controversial (indeed, different researchers draw diverse conclusions from the considered evidence!). $\mathrm{H}$ ence, rather than offering any full-fledged policy recipe, here we shall just flag some problems to be addressed and, possibly, the dilemmas involved.

\subsection{Competences capabilities and corporate performances}

First, several studies - including Pisano (2000)(A), Cockburn and H enderson (2000)(A), Patel and Pavitt (2000)(A) - add original insights on the powerful effects of competences and capabilities (cf. our earlier discussion) 
upon corporate technological performances, measured by different proxies of innovative outputs (e.g. innovations, patents, etc.).

Together, a complementary evidence is beginning to emerge concerning systematic links at firm level between organizational competences and organizational innovations, on the one hand, and technological innovation, on the other. Seetheevidencefrom national surveys discussed in Coriat (1999) and Coriat (2000a and 2000b) (B); the elaborations on a large sample of French firms by Lhuilery (2000)(B); cf. al so the study by Lay, Shapira and Wengel (1999) on the correlation between patterns of introduction of innovative organizational methods and rates of introduction of new products in the German machine tool industry.

Second, as discussed in detail by C efis (1999)(B) both the innovation and profitability profiles of firm tend to display high degrees of persistence over time.

Theanalysis of the joint distributions gives a very similar picture: firms which are systematic innovators and earn profits above the average have a high probability to keep innovating and earning profits above the average, as well as firms which are occasional innovators and earn profit below the average have a high probability to remain in the initial situation. Interestingly, the mobility in a firm's relative position with respect to the average profitability does not appear to be correlated with the firms relative position in the innovation dimension, in the short run. $\mathrm{H}$ owever, firm's relative position in the innovation dimension does matter in the long run: the probability to earn profits above the average, in the long run, is higher if a firm start as a "systematic" innovator rather than an occasional one.

Third, a few contributions have begun to explore the impact of specific organizational arrangements and organizational competences (narrow sense, cf. above) upon diverse indicators of economic perfomances of business firms: cf. in particular the diverse sources of secondary evidence critically discussed in Coriat (2000C)(B), and the statistical analyses in Lhuillery (2000)(B) and G ambardella and Torrisi (2000)(B).

So, for example, the latter paper shows the positive impact upon the market valuation of firms of both their 'technological' and 'relational' capital (notwithstanding the inevitable roughness of the statistical proxies). 
Moreover, as shown by several elaborations on national surveys discussed in Coriat (1999), (2000b)(B) - theintroduction of alarge ensemble of organizational innovations (including just-in-time, organizational provisions from 'cross-projects' team work, reduction of hierarchical layers and a few others) appear to exert in general a positive influence on the competitiveness of firms, both in terms of production costs and non-price factors (e.g. product quality, market responsiveness, etc.). If anything, the puzzling aspect in all that is the relatively slow pace of diffusion of seemingly 'superior' practices (a phenomenon al so emphasized in the case of the U S by Ichniowski et al., 2000) and their piecemeal, partial and local penetration even within a good deal of firms which do adopt them.

There appear to be multiple complementary 'retardation factors'. Some have to do with the uncertainty and gestation lags associated with future improved performances. 0 thers relate to 'political' conservatism within any organization whenever innovations bring about al so changes in hierarchies and power distribution. H owever, more fundamentally, organizational forms are carriers of history, paraphrasing D avid (1994): in particular, a history of problemsolving experienceand, together, of governancearrangements, industrial relations, authority mechanisms, salary profiles. O rganizational innovation tend to disrupt the 'epistatic correlation' across these traits, as argued at length in Levinthal (2000)(A). [See also M arengo et al. (2000)(B) and Dosi and M arengo (1999)(B)]. In our view, also thisisone of the underlying causes of the relatively low degrees of diffusion of new organizational practices and their 'timid' patterns of adoption in Europe, which often only scratch the surface of older organizational forms: cf. the evidence discussed in Coriat (2000c)(B). This latter review of various comparative studies al so highlights the influence of the institutional context - in primis, the systems of economic-wide labour relations - upon the patterns of diffusion of organizational innovations. In this respect, circumstantial evidence seems to suggest that comparatively more institutionally structured labour relations (with powerful mechanisms of collectivelabour representation, effective Business Associations, etc. ), as present in many central/northern European countries, have been indeed a factor conduciveto faster and deeper diffusion of novel organizational practices [cf. the studies cited in Coriat (2000C)(B)]. 


\subsection{From companies to sectors and countries}

The "diagnostic" aspects of the works from the D ynacom Project (cf. Dosi G., B. Coriat and K. Pavitt), as well as from other complementary studies, bear profound implications not only in terms of strategies and performances of individual firms, but - we suggest - also for the sectoral, national and regional patterns of innovation, competitiveness and growth. $M$ oreover, they relate both to the mechanisms of generation of innovative opportunities, theorganizational arrangementsthrough which opportunities are economically tapped, and their effectiveness.

O ne way of organizing the discussion of such implications is with reference to the so-called "European paradox", which claims a purported European scientific and technological strength comparable with the US and Japan but lower abilities in translating it into its economic exploitation in terms of competitiveness and growth (for a discussion of. Andreassen et al. (1995), including Coriat's and D osi's contributions therein and ESRC (1997)] and more recently Muldur (2000)].

Indeed, our evidenceallows an assessment of some of theissuesunderlying such a 'paradox' [(cf. among others, M arsili (1999)(B), Breschi and M alerba (1999)(B) and O rsenigo et al. (1999)(B)].

First, note that not only Europe is significantly weaker in terms of scientific "frontier" output in rapidly advancing fields likeICT - Information and Computation Technologies- , but thisweaknessisal so reflected in a relatively weak technological output. (See D alum et al., 1999). So, for example, B reschi and M alerba (1999)(B) show that European weaknesses in electronics technologies based on the weaknesses of both the coreand the fringe of European innovators emerges. As far as the coreis concerned, in electronics E urope does not have a big core of numerous large competent companies that span over mature as well as new technologies. In this way, big projects on broad technologies, the continuous opening of windows on new technologies and the pursuit of multitechnology initiatives that requiretheintegration of different complementary technologies may beunpaired. Asfar as thefringe of innovators is concerned, Europeischaracterised by a too high entry of small firms specialized in mature technologies. The problem here is not entry but survival. M ost of 
thenew innovators are not able to become continuous innovators and do not survive as innovators for long. Even those that survive are unable to widen their specialization, and move from mature to emerging technological fields.

Second, in a sector of historical European lead such as pharmaceuticals, the transition to a different, more directly science-based, search paradigm [ $c f .0$ rsenigo et al. (1999)(B)] has led to a weakening of the European technological and competitive positions (especially with regards to continental Europe).

Theseworrying evidence primarily concerns, to repeat, many activities based on biotechnologiesand electronics/information technologies(and notwithstanding remarkable exceptions such asmobiletelephony: see also below).

Conversely, Europe tends to maintain a position of relative strength in 'older' activities and technological paradigms (which can be characterised by low but also by high innovativeopportunities) including mechanical engineering, complex capital goods, transport equipment, chemicals and a few others [for more detailed analyses see Archibugi and Pianta (1992), Fagerberg, G uerrieri and Verspagen (1999), Fontagné et al. (2000), and M arsili (1999)(B)].

Given the patterns of technological strength and weakness of the European economy - which often largely match the technological competences of the major domestic firms (cf. Patel and Pavitt, 1998b) - , a first fundamental question concerns the effectiveness of the science and technology system in generating an expanding pool of knowledge and innovative opportunities. A second and equally crucial one regards the institutions and organizational arrangements which bridge the dynamics of innovative opportunities with their economic exploitation, most often by business firms.

Let us start with the former.

\subsubsection{Strength and weaknesses of the European science and technology system and competence accumulation in European firms}

It has not been among our central purposesto investigatethe "pure research" side of the so-called "paradox". H owever, our evidence supports some of the pieces of the interpretation discussed in Pavitt (2000a and b) and pointing at worrying structural and policy weaknesses of theE uropean research system.

First, consider the European scientific output. In general, European 
scientific productivity, evaluated in terms of European expendituresfor basic research is roughly at par with the US (possibly even marginally higher: cf. European Union, 1997).

$\mathrm{H}$ owever, the overall scientific productivity of EU -15 continues to be on average significantly lower than the USA when measured in per capita terms (by around 40\%: cf. OST, 2000). And it remains lower by more than $10 \%$ even by comparison with the EU countries with higher productivities (i.e. France, G ermany, Benelux, Scandinavia and U K). These two opposite facts are indeed easy to reconcile: the gap in public expenditures for $R \& D$ between the US and EU - 15 is of the order of several hundred billion dollars in favour of the former (M uldur, 2000).

Perhaps more revealing are the differences in the various scientific disciplines (OST: 360). EU -15 has its strongest publication performance compared to the USA in the well-established disciplines of chemistry and physics, whilst the strongest US performance is in the recently established disciplines of molecular and cellular biology, biomedical engineering, and informatics. As we shall discuss below, these are the very disciplines that are at the basis of the US strengths in biotechnology and ICT, and their development has been strongly supported by large-scale Federal funding.

Second, the R \& D performance of businessesin EU - 15 has been declining since the early 1990s relative to those in the USA, and the decline has been particularly marked in electronics (O ST, 2000, p. 364). But trends have been uneven, with declinein thelarger countries (France, Germany, I taly and UK), but growth in Scandinavian countries which have also emerged as world leaders in mobile telephony. ${ }^{7}$

Thereason usually given for such a declineareinadequaciesin technological entrepreneurship in European business reflected in low investmentsin $R \& D$. In certain cases - such as B ritish electronics and automobile companies in the 1970 s and 1980s - this was certainly the case. For other European countries, any entrepreneurial inadequacies must have emerged only in the early 1990s, sincetheir business $R \& D$ expenditures had been growing more rapidly than those in the USA during the previous twenty years. 
There is another possible explanation of the changing trends since then, namely that European firms are performing an increasing share of their $R \& D$ outside their home country, and more specifically in the USA. The analysis by Cantwell and Piscitello (1999a)(B) shows that thisisindeed the case. The major companiesin most of theEU -15 countries havebeen increasing the foreign share in their $R \& D$ activities, and at a faster rate in the 1990s. At least a third of European-based largefirms $R \& D$ isnow performed outsidetheir homecountry, of which about $20 \%$ in theU SA and $14 \%$ in other European countries. It isnot possible at this stage to assess the degree to which this shift in the location of corporate $R \& D$ can explain thestronger performance of business $R \& D$ in the USA, since U S-based businesses have also been increasing the foreign share in their own $R \& D$. But thereis increasing evidencethat foreign corporate $R \& D$ no longer is a simple support function for foreign production, but a deliberate search to learn about foreign skills and knowledge [N iosi (1999), Cantwell and Piscitello (1999b)(B), C astellani and Zanfei (1999)(B)].

Recent studies by D alton et al. (1999) and Florida (1999) show that this is particularly true of foreign corporateR \& D in the U SA, which increased from about $9 \%$ of the US total in 1987 to nearly 15\% in 1997. In the pharmaceuticals and biotechnology sector, the foreign share was as high as $49 \%$, in communications it was $20 \%$, and in computers and office equipment only $2 \%$. At least two-thirds of the foreign $R \& D$ was performed by European firms, ${ }^{8}$ who have a very powerful position in the pharmaceutical sector. Although part of this foreign $R \& D$ serves the traditional function of modifying products and practices to the requirements of the U $S$ market and regulatory regimes, its major purpose is to gain access to high-quality technical staff and developing links with thetechnical community. This is particularly true of firms involved in biotechnology, but al so holds for those in electronics.

As a consequence, foreign corporate $R \& D$ islocated mainly in regions where such talent is concentrated, sometimes in business $R \& D$ laboratories (e.g. D etroit for automobiles, $\mathrm{N}$ ew Jersey for chemical sand pharmaceuticals), and sometimes in universities. Co-operative research with U S universities is the rule rather than the exception, and they are also a common source of

8 About half, when Swiss firms are excluded. 
recruited technical staff. Themain fieldsfor such co-operation arebiotechnology and ICT, and themain regions $C$ alifornia (Berkeley and Stanford), $M$ assachusetts (MIT) and the Research TrianglePark in N orth C arolina. ${ }^{9}$

These data tend to confirm that the strength of $U S$ academic research is one of the factors causing European firms to increase the share of their research performed in the U SA, particularly in pharmaceuticals and related biotechnology, and al so in ICT. O ur point, drawing upon Pavitt (2000a and b) and earlier works of Freeman (1982), D osi (1982), Rosenberg (1982), $\mathrm{H}$ ughes (1990), among others, is that large-scale U S government funding has helped create thisstate of affairs (below we shall mention someimplications for EU policies for funding $R \& D$ ).

In the past, the academic disciplines of electrical, chemical and aeronautical engineering were pioneered in the USA. M ore recently, we have seen the development there of research and related post-graduate teaching in biotechnology and ICT-related engineering subjects.

The amount of resources matters, too: it has been estimated that the resources devoted to academic research in the life sciences in the USA are $50 \%$ bigger than in Europe (Ballantine and Thomas, 1997).

A similar pattern of funding of high quality and long-term fundamental research, from a plurality of Federal sources, emerges from a recent study of earlier developments in U S computing and software engineering (C omputer Science and Telecommunications Board, 1999).

By comparison, European policies appear to continue on an established trajectory too often conforming with the old philosophy "too little, too late, with too many strings attached... ". This has been true for past national policies toward electronics and biotechnologies [cf. D osi (1982) and O rsenigo (1989)] and it continues to largely hold for European $R \& D$ policies. In fact, the latter institutionally embody further constraintsand compromises concerning 'cohesion' and 'equity' (e.g. between big and small firms, big and small countries, theN orth and the South, etc.). O $n$ these grounds, the findings by Giarratana and Torrisi (2000)(B) on the disappointing effects of EU -sponsored research agreementsupon technological competences of European firms should not comea total surprise.

9 Other universities identified include Princeton and the Universities of Colorado and Washington. 
In fact, historically, objectives of intra-European integration and homogeneization could have justified the complexity of the allocation mechanism and the mix of diversecriteria which haveinformed EU policies.

At this stage, one wonders whether a more direct focusing on criteria of scientific quality might not be desirable if not al together necessary.

\subsubsection{Institutional differences in the mechanisms of knowledge exploitation}

Given the foregoing features of knowledge-generation in science based activities, a related, although conceptually distinct, issue regards the mechanisms of appropriability, and in particular the width, depth and length of coverage of Intellectual Property Rights. It is an issue that - as known - has come to the forefront of the policy debate following a marked extension of the IPR coverage by US legislature and practice since the 1980s - which has come to include a good deal of knowledge on life forms (genes, etc.) and of software artifacts.

Whether increases in private appropriability of innovations yield monotonically increases in thelong-term propensity to innovateremains quite controversial. (For a rather skeptical view, see for example D osi, 1997). $\mathrm{H}$ owever, it is straightforward that increases in appropriability, other things being equal, do increase a) the rents accruing to the innovators themselves, and b) their ability to attract financial investors [as theU S caseindeed shows: cf. Orsi and M oatti (2001), among others].

$\mathrm{H}$ ere, one finds indeed a policy dilemma with far-reaching implications for Europe. O ne option is of course 'to go the American way', imitating the whole set of American IPR institutions. The alternative - which a few, although possibly not all, of the $\mathbf{D}$ ynacom researchers subscribe - favours, on the contrary, distinct European institutional arrangements, centered on open science, and relatively tight boundaries to what can becomea rent-yelding asset (no matter whether the rent goes to a private agent or a public organization such as a university). The subscribers to this view do so not only on the grounds of ethical and political reasons - as important as they are but also on sheer economic grounds. In thelong-run, too much/too widean appropriability of single pieces of knowledge which contribute to the 
development of complex products (think of a new drug with a new therapeutical target, of a piece of telecom equipment, etc.) arelikely to hinder theinnovation process altogether. But, then, were one to take the 'open science route, the need for remedies to the weaknesses of the European Science System - discussed above - becomes even more urgent.

Certainly, it is hard to think of a more damaging condition than the status quo, squeezed between half-hearted attempts to imitate the US, bureaucratic rigidities and meager budgets for public science, 'directives' of the European Commission and 'resolutions' of theEuropean Parliament...

\subsubsection{Competence, capabilities and their institutional roots.}

Asthestudies makeabundantly clear, diverse sectoral systems of innovation and production are grounded in equally diverse combinations of competences and organizational capabilities. (Indeed, 'sectoral systems' areprecisely the central issue of an ongoing TSER research coordinated by Franco $M$ alerba).

In turn, a general conjecture that one is beginning to explore is that such competence/ capabilities areinstitutionally embedded, in two different senses.

First, institutions- such as those governing scientific research, workforce training, labour relations, etc. - are instrumental in the generation and maintenance of organizational competences.

Second, sector-specific combinations of corporate competences, organizational structures, strategic orientations find varying degrees of matching/mismatching with the broader institutions in which a company operate. $\mathrm{H}$ ence, one is beginning to investigate al so the interpretative value of some notion of institutional comparativeadvantage, which might render a given location conducive to a certain activity not as result of any 'physical' endowment and not even as a result of the sheer amount of knowledge generated in that location but primarily owing to the locally dominant organizational arrangements governing e.g. labour mobility, finance, corporate governance, etc. If the 'ways of doing things' display someinvariances specific to each activity (e.g. making steel, or designing/producing luxury cars, or searching for a new monoclonal antibodies, etc.) irrespectively of the nation where they are undertaken, then one may observe 'comparative advantages' 
due precisely to theinstitutional characteristics of that location which, so to speak, 'make it easy to do that particular thing in that particular way' in that particular place. [O $n$ all these points, cf. from different angles, Soskice (1996 and 1999), Amable (2000), H anke(1999), C oriat and Weinstein (1999), D osi (1999)].

Indeed, Soskice (1996 and 1999) and H anke (1999) have begun to compare, among other countries, the US and Germany, finding remarkable symmetries. W hereas the U S tend to display comparativeadvantages in activities characterized by science-based 'disruptive' innovations, G ermany finds its points of strength in activities displaying more cumulative patterns of innovation, based on intensive intra-organizational learning. In turn, the authors suggest, each of the two broad patterns is supported by 'matching' institutions' in the financial and labour markets.

A loosely complementary evidence, this time concerning the European Union as a whole, highlights a widespread bias of European exports in favour of high quality products (where 'quality' is measured by unit prices within each product category): 'high' and 'medium' qual ity production makesup for more than the double of the total European foreign surplus in manufacturing trade (with the 'low' category accounting for a significant deficit) (Fontagné et al., 2000). N otealso that this pattern does not apply to the U S trade profile- even neglecting the structural presence of an overall trade surplus in the European case and growing overall deficit in the U S case - ${ }^{10}$

Come as it may, these pieces of circumstantial evidence, together with some of theworksreviewed in Coriat [(1999), (2000b)(B)], and a few sociological investigations converge to the view that most European nations have distinctive institutional arrangements conducive to support a wide range of organizational capabilities, especially in 'older' technological paradigms, often relying on cumulative knowledge accumulation and on a highly skilled workforce.

A few European points of strength in ICT such as manufacturing automation and Telecom (especially mobile communications) are also revealing a more general lesson whereby ample opportunities for innovation and competitiveness are generated at the interface between 'old' and 'new' competences. M oreover, as the case of mobile phones highlight, a decisive

${ }^{10}$ On the relative 'quality profile' of European exports, see also Jansen and Landesmann (1999), who however find wide intra-European differences. 
role has been played by "the joint effort between (public) telecom service providers, telecom regulators and private firms", showing "how public-private cooperation at the institutional level may be a decisive factor in enhancing the competitiveness of European firms" (D alum et al., 1999, p. 123).

\section{Is there any 'one best way'? Some final policy remarks}

Certainly, onegeneral lesson of this research isthat onecan hardly identify "one best way" to accumulation of organizational competences and competitiveness. Rather, the research has begun to make some painstaking inroads toward the identification of some sort of "combinatorial exercises" amongst scientific, technological, and organizational arrangements conducive to microeconomic competitiveness. H owever, the absence of any invariant "best", does not mean that "anything goes". O n the contrary, all across the wide range of institutions, organizational arrangements and policies, one may identify both some necessary conditions and some "combinatorial constraints".

Begin with 'pure research' domain.

Asdiscussed in Pavitt (2000aand b), the experience of theU SA shows that government support of high quality academic research has far reaching positive economic consequences, in both creating technological and economic opportunities and providing the skills and knowledge to attract high-tech businesses. $\mathrm{H}$ igh quality academic research in itself is a necessary but not sufficient basisfor technological dynamism (Florida, 1999). But there is evidence that the direct practical usefulness of the results of 'pure' academic research is extending beyond molecular biology and biotechnology (M owery et al., 2000). ${ }^{11}$ This experience, and the above comparisons with Europe, strongly suggest that similar policies in Europe will help redress the balance of technological performancein itsfavour in the future. H owever, this will requiremajor changes in the priorities and practices in the science and technology policies of theEU.

The first major change at this level is that the strengthening of high quality academic research should become one of the principle objectives of

\footnotetext{
"See, for example, in a range of fields, massive computing power now enables academic-based researchers to develop and test technical concepts through virtual prototyping, and thereby become an increasingly important source of technology - based firms Mahdi and Pavitt, 1997; Koumpis and Pavitt, 1999.
} 
EU policies. EU funding of academic research should complement and compete with national sources of funding, and not replace them, for the following reasons.

- Thespread of theeconomic benefits of publicly funded research in Europe is extending increasingly acrossnational boundariesin Europe, reflecting thelong term increasein Europe-wide collaboration and the growth in the establishment of corporate $R \& D$ laboratories of European companies in a number of European countries. A greater share of EU widefunding of academic research would increasetheal ignment between the sources of funding and those benefiting from their results.

- The casefor continuing EU funding of "near market" corporateR \& D is weakening. Evaluations of past experience show that EU programmes are most effective in establishing networks, and accumulating science and engineering competencies (Peterson and Sharp, 1998). ${ }^{12} M$ aking high quality European academic research an increasingly important component of such networks and competencies will help establish a stronger basisfor EU -based innovative activities.

- TheU S experience shows that pluralism in funding sources increases variety, and thelikelihood that promising research will be supported.

- It al so increasescompetition amongst both the founder and thefunded, thereby both increasing quality. Connerade (2000) has recently pointed out that one of the major supposed benefits of the EU - competition on a Europe-widebasis- is denied in public research, sinceboth funding and execution are mainly nationally based and protected. EU funding would create at least one element of such competition.

$\mathrm{H}$ aving said that, however, it would be a major mistake, in our view, to conceive the policy measures aimed at the (urgent!) improvement of the European Science and Technology System, drawing upon the fundamental experience of the U S after World War II, as part of a naïve package to 'catchup' in toto with a purported 'American model'. Rather, thetricky issue here is

\footnotetext{
${ }^{12}$ As the experience in mobile phones shows, establishing EU-wide standards is also widely appreciated by business practitioners.
} 
how to introduce changes which are not harmful to the 'relative institutional advantages' of the European socio-economic fabric. O ne example we discussed above regarded precisely the strengthening of research institutions cum 'open science'.

Another case to the point is the safeguard of the institutions (e.g. in labour relations) which support the accumulation of a distinct set of organizational competences.

Of course, one thing is the generation of new scientific and technological knowledge, and another is its economic exploitation - even if, as abundantly argued, the two processes are dynamically coupled. Indeed, a good deal of research has addressed that side of both processes involving primarily business firms, and the importance of their structures, strategies and organizational practices - in general, and in particular of European firms.

Let usjust mention a few diagnostic issues ridden with normativeimplications.

Against a general background of increasing globalization, particularly in product markets and in foreign direct investment, one repeatedly notices nonethelessa continuing importance of company-specific organizational practices in managing the processes of charge. Together, institutional (often, but not al ways country-based) specificities appear to exert a powerful influenceon organizational arrangements and on microeconomic performances [cf., among others, Florida and Kenney (2000) (A), Coriat (2000) (A), Fujimoto (2000) (A), Lhuillery (2000) (B), Lorenz and Lazaric (1999) (B), Coriat (2000C) (B)].

All thisisintertwined with the deep modificationsinduced by new technologies and in particular ICTs upon organizational forms and skill profiles of the workforce. As, for example, Balconi (2000)(B) shows, ICT-based systems of control, that increasingly underliemanufacturing systems, lead to different forms of internal forms of corporateorganization (flatter hierarchies), different industrial structures (vertical disintegration) and different workforce skills (high general levels of education, rather than specific artisanal skills). Theresults will bestronger competition from certain newly industrialising countries, and pressurefor Europe to specialise in more knowledge-intensive industrial segments, with a greater emphasison $R \& D$ and design activities.

Automation and codification of knowledge in sectors largely unaffected by the older "Fordist/Taylorist revolution" is increasing the weight of fixed 
costs and, together, isfostering outsourcing and specialization (good sectoral cases to the point are steel and other metal processing industries, textiles, food processing and few segments of themechanical sector). All this, Balconi (2000)(B) argues, engenders a sort of polarization across and within sectors depending on the relative importance of cognitive entry barriers.

Thelatter are high wherever problem-solving and new knowledge creation are central to the related production activities. Conversely, areas where innovation is mainly embodied in plants and equipment, the reliance upon the tacit knowledge of skilled workers has been falling, due to the codification of know-how and its embodiment into machine software: together "cognitive" entry requirements have fallen. Plant workers, machine suppliers, software developers and consultants - all activities where cognitive entry barriers are high - have increasingly developed capabilities enabling new "downstream" entrants to more easily acquire the knowledge needed to start production from scratch.

This divide also maps into deep changes in the international division of labour, progressively eroding traditional points of European strength - such as those based on tacit production skills - and, at the same time, challenging Europe to foster those segmentscharacterized by a crucial content of problemsolving activities.

At a more normative level, one implication of our findings for technology policies is the need to take into account the increasing importance of a wide range of technologies - such as materials and instrumentation -, as well as "older" serendipitous competences - such as those in mechanical engineering and not just those related to computing and IT - .

As several studies suggest, however, corporate (and most likely national and regional) performances are shaped by the interacting processes of technological and organizational innovation. W ith regards to the former, the project, wehope, has contributed to further advance our understanding of the patterns of technological accumulation - within and outsidecorporateorganizations-, and with that also a hopefully better appreciation of the policy instruments aimed at thegeneration and exploitation of scientific and technological knowledge.

$W$ ith reference to organizational innovation, a few studies have begun to contribute to the painstaking exploration of the links between nature of the 
institutional context and patterns of organizational change - with that trying to give also a little bit more operational content to the adagio that the specificities of European institutions are not just a drawback but might bea major collective resource. Indeed, the major 'paradox' in the contemporary European scene might well be the fact that we significantly underestimate the potential for organizational innovation and competitiveness inherent in a few European institutions - including its training systems, its representation mechanism, its patterns of labour relations -, clumsily trying to 'catch-up' with parts of an idealized 'American' model, whileat the sametimeneglecting some crucial positive lessons coming from that very model - for example, concerning science-based competence accumulation.

\section{Bibliography}

Amable, B. (2000). "Institutional Complementarity and D iversity of Social Systems of Innovation and Production", Review of International Political Economy (forthcoming), 2000.

Andreassen, L., B.; Coriat, F.; D en H artog; R. Kaplinsky (eds.), Europés N ext Step - Organizational Innovation, Competition and Employment, London: Ed. Frank Cass, 1995.

Archibugi, D .; M. Pianta, The technological Specialization of Advanced Countries, D orthrecht, K luwer, 1992.

Balconi, M . (B). "Codification of technological knowledge, firm boundaries, and 'cognitive' barriers to entry", DYNACOM Working Paper, 2000.

Ballantine, B.; S. Thomas Benchmarking the Competitiveness of Biotechnology in Europe, Business Decisions Ltd., 1997.

Breschi, S.;F. M alerba (B)., "Diversification and Specialisation in Innovative Activities: An Analysis of Patenting Activity of Electronic Firms", D YN ACOM Working Paper, 1999. 
Cantwell, J.; L. Piscitello (B). "Accumulating technological competence - its changing impact on corporate diversification and internationalisation", DYNACOM Working Paper.; a revised version is published in Industrial and Corporate Change, (2000), vol. 9, $\mathrm{n}^{0} 1$, p. 21-51, 1999a.

Castellani, D.; A. Zanfei, (B), "M ultinational experience, absorptive capacity and knowledge exploitation. A comparative analysis of the electronics and chemical industries", D YNACOM Working Paper, 1999.

C efis, E., (B). "Persistence in Profitability and in Innovative Activities. comparison between European, US and Japanese firms", DYN ACO M Working Paper, 1999.

Cockburn, I.; R. H enderson (A). "M easuring Competence? Exploring Firms Effects in D rug Discovery", in Dosi et al. (eds.), 2000.

Computer Science and Telecommunications Board, Funding a Revolution: Government support for Computing Research, $\mathrm{N}$ ational Research Council, Washington, D.C., 1999.

Conner, K.R.; C.K. Prahalad, "A resource-based theory of the firm: knowledge vs. Opportunism", Organization Science, v. 7, p. 477-501, 1996.

Connerade, J-P. , "European Science Policy: just where is it going?", Euroscience N ews, n. ${ }^{0}$ 10, January: 1, 2000.

Coriat, B., L'innovation Organisationnelle dans les Firmes Européennes - Nature, Diffusion, Performances Premiers Jalons, Rapport pour la DG-III, D ocument CREI, Université Paris, v. 13, 1998.

"The 'Abominable O hno Production System'. Competences, Monitoring, and Routines in Japanese Production Systems", in Dosi et al. (eds.), 2000 (A).

; "Compétences, Structures de Gouvernance et Rente Relationnelle. Le Cas de la Conception des Grands Projets Complexes", DYNACOM Working Paper, 2000a (B)

"O rganisational nnovation in European irms: A Critical O verview of the Survey Evidence", DYN ACOM Working Paper, 2000b (B)

, "T he State of O rganisational Reform in the European Firms. Evidence From a Comparative 0 verview of Ten EU Countries", DYNACOM Working Paper, 2000c (B).

; D osi, G., "Learning How To Govern and Learning H ow To Solve Problems : on the $\mathrm{Co}$-Evolution of $\mathrm{Competences,} \mathrm{C}$ onflicts and $\mathrm{O}$ rganizational 
Routines", in Chandler, Jr.,A.D .; H agström, P. ; Sölvell, Ö. (eds.) 1998, The D ynamic Firm, O xford: O xford U niversity Press, 1998a.

; Weinstein, 0. "Firms and Institutions in the Innovation Generation. Towards a Theory of 'C orporate Systems of Innovation' ". Paper prepared for the D ruid Conference on National Innovation Systems, Industrial Dynamics, and Innovation Policy, Rebild, Denmark, p. 9-12 jun., 1999.

Dalton, D., M. Serapio and P. Yoshida Globalizing Industrial Research and D evelopment, U.S D epartment of Commerce, Washington, 1999.

D alum, B. ; Freeman, C.; Simonetti, R.; Tunzelman, N .V.; Verspagen, B. "Europe and the Information and Communication Technologies Revolution", in Fagerberg, P. Guerrieri and B. Verspagen (eds.) 1999.

D avid, P.A., "W hy are Institutions 'the Carriers' of H istory? Path-dependence and the Evolution of Conventions, $O$ rganizations and Institutions", Structural Change and Economic D ynamics, v. 5, n², 1994.

D ierickx, I.; C ool, K., "Asset Stock Accumulation and Sustainability of Competitive Advantage', M anagement Science v. 35, p. 1504-1511, 1989.

D osi, G., "Technological Paradigms and Technological Trajectories. A Suggested Interpretation of the D eterminants and Directions of Technical Change", Research Policy, v. 11, p. 147-162, 1982.

, "O pportunities, Incentives and the Collective Patterns of Technological Change", Economic Journal, v. 107:144, p. 1530-1548, 1997.

, "Some N otes on National Systems of Innovation and Production, and their Implications for Economic Analysis", in Archibugi D., Howells, J.; Michie, J. (eds.), Innovation Policy in a Global Economy, Cambridge, Cambridge University Press, p. 35-48, 1999.

, Coriat, B.; Pavitt, K. , "Competences, Capabilities and Corporate Performances". D ynacom Project, 2002.

Egidi M., "Substantive and Procedural Uncertainty. An Exploration of Economic Behaviours in Changing Environments", Journal of Evolutionary Economics, 1991.

, M arengo, L., "Some Elements of an Evolutionnary Theory of Organizational Competences", in England, R. W. (ed.), Evolutionary Concepts in Contemporary Economics, Ann Arbor: University of M ichigan Press, 1994. ; "On the Tangled Discourse between Transaction Costs 
Economics and Competence-based Views of the Firm: Some Comments", DYN ACOM Working Paper, 1999 (B).

Edquist, C. (ed.), Systems of Innovation: Technologies, Institutions and O rganizations, London: Pinter, 1997.

European Union. Second European Report on Science and Technology Indicators, Brussels, European Commission, Report EUR 17639, 1997.

Fagerberg, J.; Guerrieri, P.; Verspagen, B. (eds.). The E conomic Challenge for Europe. Adapting to Innovation Based Growth, Aldershot: Edward Elgar, 1999.

Florida, R. (1999). "The Role of the Universities: Leveraging Talent not Technology", Issues in Science and Technology Online, www.nap.edu/issues/15.4/florida.htm

Florida, R.; Kenney, M ., "Transfer and Replication of O rganizational C apabilities", in Dosi et al. (eds.), 2000 (A).

Fontagné, M ., Freudenberg, M .; Ü nal-K esenci, D. "La spécialisation technologique des pays Européens", in D elapierre, I., Ph.; M oati, El M. M ouhoud (eds.), Connaissance et M ondialisation, Economica, Paris, 2000.

Freeman, C., The Economics of Industrial Innovation, London: Pinter, 2ª edn., 1982.

Fujimoto T., "Evolution of M anufacturing Systems and Ex Post D ynamic Capabilities', in D osi et al. (eds.) 2000 (A).

Gambardella, A.; Torrisi, S., (2000)(B). "The Economic Value of Knowledge and Inter-firm Technological Linkages: An Investigation of Science-Based Firms", DYN ACOM Working Paper., 2000 (B).

Giarratana, M .; Torrisi, S., "Competence Accumulation and Collaborative Ventures: Evidence from the Largest European Electronics Firms and Implications for the EU Technological Policies', DYNACOM Working Paper. 2000 (B).

Grant, R.M., Contemporary Strategy Analysis: Concepts, Techniques, Applications, $2^{a}$ edn. Cambridge, M ass.: Blackwell, 1995.

"Toward a Knowledge-based Theory of the Firm", Strategic M anagement Journal, v. 17 (W inter special issue): p. 109-122, 1996.

$\mathrm{H}$ anke, B. "Varieties of Capitalism Revisited. Globalisation and Comparative Institutional Advantage", La Lettre de la Régulation, Paris, September, n³0, 1999.

Hughes, T. P., American Genesis: a Century of Invention and Technological Enthousiasm, Penguin Books, 1990. 
Ichniowski, C.; Levine, D .; O Isen, C.; Strauss, G. (eds.) The American. Workplace Cambridge: Cambridge U niversity Press, 2000.

Jansen, M .; Landesmann, M., "European Competitiveness: Q uality Rather than Price", in Fagerberg, J., Guerrieri, P.; Verspagen, B. (eds.) 1999.

Kogut, B.; Zander, U. "Knowledge of the Firm, Combinative Capabilities, and the Replication of Technology", O rganizations Science, v. 3: p. 383-97, 1992.

"K nowledge, $\mathrm{M}$ arket Failure and the Multinational Enterprise: a Reply", Journal of International Business Studies, 1995.

Koumpis, K.; Pavitt, K., "Corporate Activities in Speech Recognition and $\mathrm{N}$ atural Language: Another 'N ew-Science' - Based Technology", International Journal of Innovation M anagement, vol. 3, p. 335-336, 1999.

Levinthal, D., "O rganizational Capabilities in Complex Worlds", in Dosi et al. (eds.) 2000 (A).

Lhuillery, S. "The O rganizational Practices of Innovation and the Performances of Firms: An Empirical Investigation", DYN ACOM Working Paper, 2000 (B).

Lorenz, E.; Lazaric, N ., "T heTransfer of Competences to European-Based Japanese Affiliates", DYN ACOM Working Paper, 1999 (B).

Lundvall, B. A. (ed.), National Systems of Innovation, London: Pinter, 1992.

Madhok, A. "'The Organization of Economic Activity: Transaction Costs, Firm Capabilities and the Nature of Governance", Organization Science, v. 7, p. 577-90, 1996.

M ahdi, S.; Pavitt, K., "Key N ational Factors in the Emergence of Computational Chemistry Firms", International Journal of Innovation M anagement, vol. 1: $p$. 355-386, 1997.

March, J.G., A Primer on Decision M aking, New York: Free Press, 1994.

M arch, J.G.; Simon, H. A., Organizations, 2a edn., Cambridge, M A: Blackwell, 1993.

M arengo L.; Dosi, G .; Legrenzi, P.; Pasquali, C., "The Structure of Problem-

Solving K nowledge and the Structure of O rganisations", DYN ACOM Working Paper, 2000 (B).

M arsili, O., "Techological Regimes: Theory and Evidence", DYNACOM Working Paper, 1999 (B).

M etcalfe, J. S., "Evolutionary Economics and Technology Policy", Economic Journal, v. 104: p. 931-44, 1994. 
M iyazaki, K., Building Competences in the Firm: Lessons from Japanese and European O ptoelectronics, New York: St. M artin Press, 1995.

M owery, D.; N elson, R.; Sampat. B.; Ziedonis, A., "T he effects of the Bayh-D ole Act on US Academic research and technology transfer", Research Policy, (forthcoming), 2000.

Muldur, U., "L'allocation des capitaux dans le processus global d'innovation estelle optimale en Europe?", in Cohen, E.; Lorenzi, J. H. (eds.), Politiques Industrielles pour l'Europe, Paris, Cahiers du Conseil d'Analyse Economique, Premier M inistre, La D ocumentation Française, 2000.

N elson, R. R. "W hy do Firms D iffer, and D oes it M atter ?", Strategic M anagement Journal, v. $12: 61-74,1991$.

(ed.), N ational Systems of Innovation: a ComparativeStudy, 0 xford: 0 xford University Press, 1993.

; W inter, S.G., An Evolutionary Theory of Economic Change, Cambridge M A: H arvard University Press, 1982.

Niosi, J., "Introduction: the Internationalisation of Industrial $R \& D$ : From Technology Transfer to the Learning O rganisation", Research Policy, v. 28: 107117, 1999.

O rsenigo, L., The Emergence of Biotechnology, $\mathrm{N}$ ew York: St. Martin Press, 1989.

Orsenigo, L.; Pammolli, F.; Riccaboni, M. "Competencies, Technological Change and N etwork Dynamics. The Case of the Bio-pharmaceutical Industry", DYN ACO M Working Paper, 1999 (B).

Orsi, F.; Ph. M oatti. "Les nouvelles relations Science et Industrie dans le domaine du Génome Humain : Vers un nouveau Statut de la Connaissance", under revision for Economie et Prévisions, 2001.

OST (L'O bservatoire des Sciences et des Techniques)(2000). Science et Technologie Indicateurs, Economica, Paris, 2000.

Patel, P.; Pavitt, K., "T heW ide (and Increasing) Spread of Technological Competences in the World's Largest Firms: a Challenge to Conventional Wisdom", in Chandler, A. D ., Jr.; H agström. P.; Sölvell, Ö . (eds.), The D ynamic Firm, O xford University Press, 1998a.

Patel, P.; Pavitt, K., "Uneven (and divergent) Technological Accumulation among 
Advances Countries. Evidence and a Framework of Explanation", in Dosi, G.; Teece, D. J.; Chytry, J., Technology, O rganization and Competitiveness Perspectives on Industrial Corporate Change, O xford University Press, (1998b).

the Firm", in Dosi et al. (eds.) 2000 (A).

Pavitt, K., "Academic Research in Europe", Working Paper, SPRU, 2000a.

, "Public Policies to Support Basic Research: What can the rest of the world learn from US theory and practice? (And what they should not learn)", Working Paper, SPRU, 2000b.

Penrose, E., The Theory of the Growth of the Firm, N ew York: Wiley, 1959.

Peterson, J.; Sharp, M., Technology Policy in the European Union, Macmillan, Basingstoke, 1998.

Pisano, G. P., "In Search of Dynamic Capabilities", in Dosi et al. (eds.), 2000 (A). Porter, M . E., "W hat is strategy?", H arvard Business Review, 1996.

Rosenberg, N ., Inside the Blackbox, Cambridge: Cambridge University Press, 1992.

Rumelt, R.; Schendel, D.; Teece, D., "Strategic management and economics", Strategic M anagement Journal, v. 12: 5-29, 1991.

Soskice, D. German Technology Policy, Innovation, and National Institutional Frameworks, Berlin, WZB Discussion Paper, FS I 96-319, 1996.

, "Divergent Production Regimes: Coordinated and Uncoordinated M arket Economies in the 1980s and 1990s", in Kitschelt, H .; Lange, P.; M arks, G.; Stephens, J.D. (eds.), Continuity and Change in Contemporary Capitalism. Cambridge: Cambridge University Press, 1999.

Stalk, G.; Evans, P.; Shulman, L. E., "Competing on Capabilities: the New Rules of Corporate Strategy", H arvard Business Review, M arch-April : 57-69, 1992.

Teece, D .; Rumelt, R.; D osi, G.; W inter, S., "Understanding Corporate Coherence: Theory and Evidence", Journal of Economic Behavior and Organization v. 23: 130, 1994.

; Pisano, G., "The D ynamic Capabilities of Firms : An Introduction". Industrial and Corporate Change, v. 3, n 3, 1994.

; Shuen, A., "D ynamic Capabilities and Strategic M anagement", Strategic M anagement Journal, v. 18: p. 509-33, 1997. 
M anagement", in D osi et al. (eds.) 2000.

Tjissen, R; van Wijk, E. "In Search of the European Paradox: An International Comparison of Europe's Scientific Performance and Knowledge Flows in Information and Communications Technologies Research", Research Policy, v. 28: 519-543, 1999.

Warglien, M ., "The Evolution of Competences in a Population of Projects: a Case Study", DYNACOM Working Paper, 1999 (B).

Weinstein, O .; Azoulay, N., "Firms' Capabilities and Organizational Learning. A Critical Survey of Some Literature", DYN ACO M Working Paper, 1999 (B).

Williamson, O.E., Strategy Research: "Governance and Competence Perspectives", Strategy Research: "Governance and Competence Perspectives", Strategic M anagement Journal, v. 20(12), p. 1087-1109, 1999a.

, H uman Actors and Economic O rganization, Berkeley, U niversity of California, mimeo, 1999b.

Winter, S.G., "An Essay on the Theory of Production", in H ymans, H. (ed.), Economics and theWorld around It, Ann Arbor: University of M ichigan Press, $p$. 55-93, 1982.

"O $n$ C oase, Competence, and the Corporation", Journal of Law, Economics, and Organization, v. 4: p. 163-180, 1988. 